\title{
Macrophage-Derived Chemokine Expression in Classical Hodgkin's Lymphoma: Application of Tissue Microarrays
}

\author{
Cyrus V. Hedvat, M.D., Ph.D., Elaine S. Jaffe, M.D., Jing Qin, Ph.D., Daniel A. Filippa, M.D., \\ Carlos Cordon-Cardo, M.D., Ph.D., Giovanna Tosato, M.D., Stephen D. Nimer, M.D., \\ Julie Teruya-Feldstein, M.D. \\ National Cancer Institute, National Institutes of Health, Bethesda, Maryland (ESJ, GT); Department of \\ Medicine, Molecular Pharmacology and Therapeutics Program, Sloan Kettering Institute, New York, New \\ York (SND); and Departments of Epidemiology and Biostatistics (JQ) and Pathology (DAF, CCC, JTF, \\ CVH), Memorial Sloan Kettering Cancer Center, New York, New York
}

Hodgkin's disease (HD) is a lymphoid malignancy characterized by the presence of Reed-Sternberg (RS) and Hodgkin's cells in a background of mixed inflammatory cells and stromal reaction. Studies have documented that HD is a neoplasm associated with abnormal cytokine and chemokine production. To define the expression of macrophagederived chemokine (MDC) in HD, 57 cases (18 lymphocyte predominant, 11 mixed cellularity, 28 nodular sclerosis) were stained for MDC by immunohistochemistry and compared with reactive lymph nodes as controls. MDC was expressed by RS cells in classical HD (CHD) and showed a distinct cytoplasmic and Golgi localization. Accumulating evidence suggests that lymphocyte-predominant HD (LPHD) represents an entity distinct from CHD, with different biological properties and clinical course. On the basis of the high level of MDC staining alone, CHD could be distinguished from LPHD $(P<.001)$, which showed only faint staining of scattered histiocytes similar to control tissues. CHD cases with high MDC mRNA levels showed high levels of MDC protein expression by immunohistochemistry $(P<.001)$ and significant eosinophil infiltration, suggesting that MDC may represent another molecule that plays a critical role in eosinophil recruitment. We also analyzed 102 cases of non-Hodgkin's lymphoma and normal spleen,

Copyright (C) 2001 by The United States and Canadian Academy of Pathology, Inc.

VOL. 14, NO. 12, P. 1270, 2001 Printed in the U.S.A

Date of acceptance: September 5, 2001

This work was presented in part at the 90th Annual Meeting of the United States and Canadian Academy of Pathology, March 3-9, 2001, in Atlanta, Georgia.

Supported in part by grants from the Norman and Rosita Winston Foundation $(\mathrm{CVH})$ and the Sports for a Cure Foundation (CVH, SDN).

Address reprint requests to: Julie Teruya-Feldstein, Department of Pathology, Memorial Sloan-Kettering Cancer Center, 1275 York Avenue, New York, NY 10021; e-mail: feldstej@mskcc.org; fax: 212-717-3203. lymph node, and thymic tissue. High levels of MDC expression were specific to CHD cases because only low levels of MDC were observed in a minor subset of LPHD, NHL or normal lymphoid tissues.

KEY WORDS: Chemokine, Hodgkin's lymphoma, Lymphoma, MDC, Tissue microarray.

Mod Pathol 2001;14(12):1270-1276

Hodgkin's disease (HD) is a lymphoid malignancy characterized by the presence of Reed-Sternberg (RS) and Hodgkin's cells in a background of mixed inflammatory cells and stromal reaction. A number of studies have documented that HD is a lymphoid neoplasm associated with abnormal cytokine and chemokine production (1-3), and we have shown that HD tissues express elevated levels of the chemokines IP-10, Mig, MIP-1 $\alpha$, RANTES, and eotaxin (4), whereas others have found increased expression of TARC (5). These locally produced chemokines may be responsible for the cellular infiltrates in HD tissues by promoting selective cell migration.

Macrophage-derived chemokine (MDC) and TARC are CC chemokines that function through the CCR4 receptor, promoting chemotaxis of monocytes, monocyte-derived dendritic cells, eosinophils, and NK cells (6). MDC is constitutively expressed by thymic medullary epithelial cells and macrophages and by activated $\mathrm{B}$ and $\mathrm{T}$ lymphocytes $(7,8)$. MDC expression in macrophages is enhanced by IL- $1 \alpha$, TNF- $\alpha$, and LPS (9). Although eosinophils do not express CCR4, they migrate in vitro in response to MDC (10).

Nodular lymphocyte-predominant (LP) HD is characterized histologically by the presence of lymphocytic and histiocytic (L\&H) cells in a background of small lymphocytes and histiocytes. There is mounting evidence that LPHD represents a dis- 
tinct entity from classical HD (CHD), including the immunophenotype of these L\&H cells, biological factors, and clinical behavior $(11,12)$. We have previously shown that MDC mRNA expression was significantly higher in the NS subtype as compared with in the other HD subtypes $(P=.002$; 13$)$; however, the cellular origin of MDC protein expression was not assessed. The expression and function of MDC in neoplasia is only beginning to be defined. This study further investigates the role of MDC in the pathogenesis of $\mathrm{HD}$ and its potential use as a specific diagnostic marker distinguishing classical from LP HD.

Tissue microarrays (TMAs) allow parallel analysis of hundreds of tissues on a single glass slide (14), and have been used to study several types of tumors, including non-Hodgkin's lymphomas (15-18), although no studies of HD with this technique have been reported. These tissues can be analyzed using standard light microscopy, immunohistochemistry (IHC), or in situ hybridization (ISH). We have applied the tissue microarray technique to NHL and HD tissues to rapidly analyze the specificity of MDC expression.

\section{MATERIALS AND METHODS}

\section{Case Selection}

Lymph node biopsies were retrieved from the consultation files of one of us (ESJ) in the Hematopathology Section, Laboratory of Pathology, National Cancer Institute (NCI) of the National Institutes of Health $(\mathrm{NIH})$, and the pathology files from the Department of Pathology, Memorial SloanKettering Cancer Center (MSKCC). Sixteen previously published HD cases from the NCI (13) and 41 additional HD cases with adequate clinical follow-up from MSKCC were selected. Immunohistochemical analysis for MDC expression was conducted on all $57 \mathrm{HD}$ cases that were further subclassified as mixed cellularity (MC, $n=11$ ); nodular sclerosis (NS, $n=28$ ); and LP (LP, $n=18$ ). No cases of lymphocyte-rich or lymphocyte-depleted classical HD were included. Seven control cases of reactive lymphoid hyperplasia (RLH) were also studied. HD cases were classified according to the REAL/ World Health Organization classification (19). Neoplastic RS or Hodgkin's cells stained positive with LeuM1 (CD15) and BerH2 (CD30) in the MC and NS subtypes; lymphocytic and histiocytic (L\&H) "popcorn" cells stained positive for L26 (CD20) in the nodular LP subtype. A total of 102 NHL including chronic lymphocytic leukemia/small lymphocytic lymphoma (CLL/SLL, $n=13$ ), follicular lymphoma (FL, $n=36$ ), diffuse large B-cell lymphoma (DLBL, $n=26$ ), anaplastic large cell lymphoma (ALCL, $n=$ 10), mantle cell lymphoma (MCL, $n=5$ ), marginal zone lymphoma (MZL, $n=5$ ), and T-cell/ histiocyte-rich large B-cell lymphoma (TCRBCL, $n$ $=7$ ) were selected and studied.

\section{Tissue Microarray Construction}

TMAs were constructed using a manual tissue arrayer (Beecher Instruments, Silver Spring, MD). A total of $34 \mathrm{HD}$ cases (6 LP, $7 \mathrm{MC}, 21 \mathrm{NS}$ ) from the MSKCC group and control normal lymphoid tissues were selected for the HD TMA, and 87/102 NHL and normal or reactive lymphoid tissues (lymph node, thymus, spleen, and tonsil) for the NHL array. The HD array consisted of 91 cores $1 \mathrm{~mm}$ in diameter, with an edge-to-edge spacing of $0.5 \mathrm{~mm}$. The NHL array had a total of 235 cores $0.6 \mathrm{~mm}$ in diameter and $0.2 \mathrm{~mm}$ spacing. The cores, $1-3 \mathrm{~mm}$ in length, were transferred to an empty recipient paraffin block $(45 \times 20 \times 10 \mathrm{~mm})$. H\&E-stained slides and corresponding paraffin blocks (prepared from either formalin- or B3-fixed tissue) were aligned to select the area for coring by the arrayer. At least two cores were taken from each block for every case. Five- $\mu$ m-thick sections of both TMA blocks were cut on a microtome. H\&E staining of the TMA was performed to verify the presence of diagnostic areas from NHL cases. HD TMA sections were stained for CD3, CD4, CD8, CD20, CD30, CD15 (LeuM1), and MDC. Representative RS $\left(\mathrm{CD} 30^{+}, \mathrm{CD}_{15^{+}}, \mathrm{CD} 20^{-}\right)$ or $\mathrm{L} \& \mathrm{H}$ cells $\left(\mathrm{CD} 30^{-}, \mathrm{CD} 15^{-}, \mathrm{CD} 20^{+}\right)$were identified in all interpretable HD cores (Fig. 1A).

\section{Immunohistochemistry and Antibodies}

A detailed characterization algorithm was followed using the following pretreatment conditions with a negative control: $0.05 \%$ pepsin in $0.01 \mathrm{~N} \mathrm{HCL}$; $0.05 \%$ trypsin in tris-HCL, $\mathrm{pH} 7.6 ; 0.05 \%$ protease XXIV in tris-HCL, $\mathrm{pH} 7.6 ; 0.01 \%$ pronase or protease XIV in tris-HCL, pH 7.6; 0.01 м citrate buffer, $\mathrm{pH}$ 6.0; 1 mм EDTA, pH 8.0; urea, pH 9.45-9.6; and no pretreatment. Slides were incubated with rabbit anti-human MDC purified antiserum (1:10,000 dilution, Peprotech, Inc, Rocky Hill, NJ) overnight at $4^{\circ} \mathrm{C}$ in a humidified chamber. Antibody dilutions were made in $1 \%$ BSA/PBS. Bound antibodies were detected with a biotinylated secondary goat antirabbit antiserum (1:500 dilution, Vector) in 1\% BSA/ PBS for 60 minutes at room temperature in a humidified chamber. Whole sections and TMAs were stained for MDC using the same protocol. MDC expression was graded by two independent observers $(\mathrm{CVH}, \mathrm{JTF})$ on a four-grade scale for positive cytoplasmic immunoreactivity in RS tumor cells. A score of 0 indicated no staining; $1+$, faint staining in less than $10 \%$ of RS cells; $2+$, a moderate intensity level of staining in $10-50 \%$ of RS cells, and $3+$, for homogenously strong intense staining in greater 

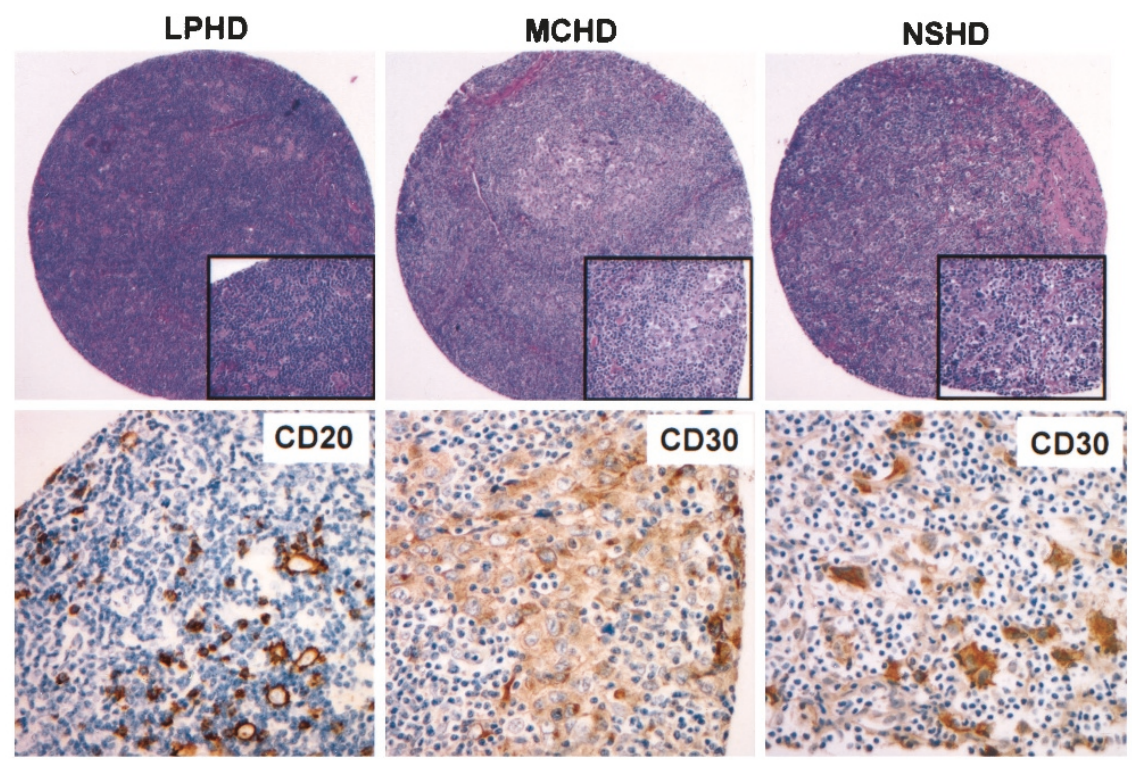

B

LPHD

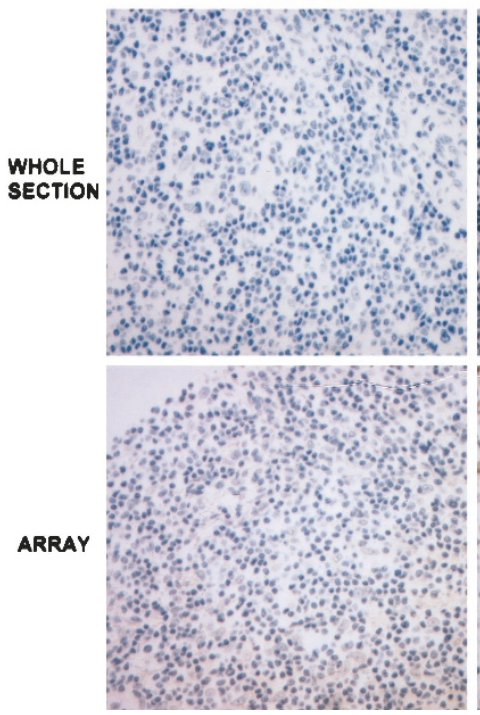

MCHD
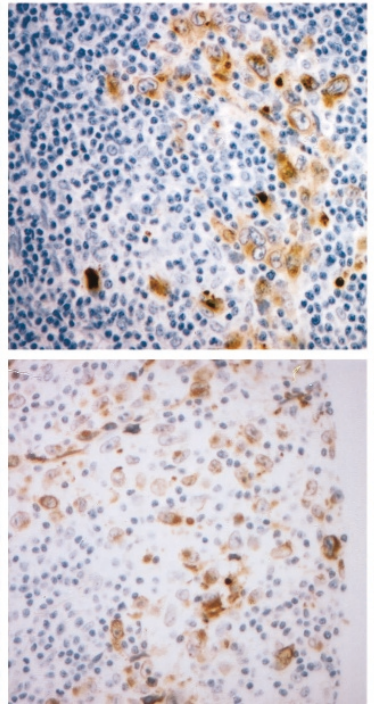

NSHD
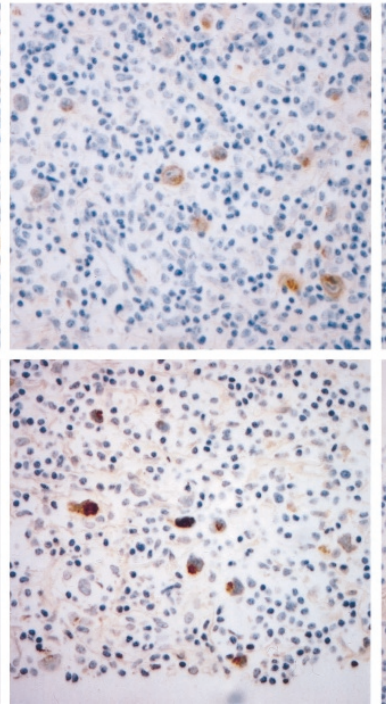

RLH
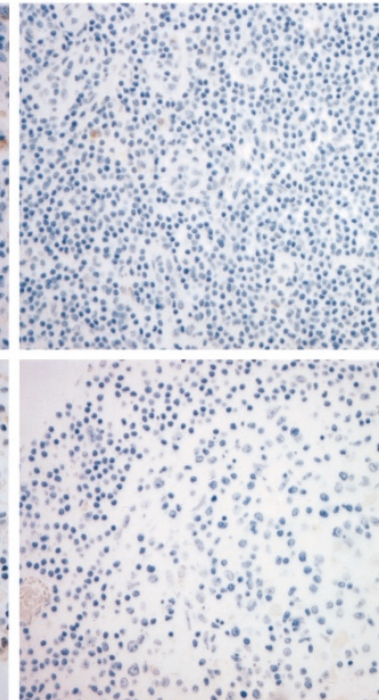

FIGURE 1. Immunohistochemical analysis of Hodgkin's lymphoma tissue: comparison of whole and tissue microarray sections. A, Paraffinembedded TMA sections were stained with hematoxylin and eosin (H\&E; upper panels; 100×; inset, 400×), anti-CD20, and anti-CD30. CD20-positive L\&H cells are identified in LPHD TMA cores, and CD30-positive RS cells are identified in MCHD and NSHD cores. B, Whole (upper panels) and TMA (lower panels) sections were stained with anti-MDC $(400 \times)$.

than $50 \%$ of RS cells. The number of eosinophils was determined by counting at least 20 separate high-power fields (HPFs) using an ocular grid eyepiece and calculating the mean number of eosinophils/HPF. Within a given section, we selected areas involved by HD containing the highest density of eosinophils. Selected areas involved by HD containing a high density of eosinophils correlated, in general, with the overall high number of eosinophils for a given case. Cases with moderate eosinophilia throughout a tumor could indeed represent a higher number than foci of intense eosinophilia; however, counting $20 \mathrm{HPFs}$ and calculating the mean number of eosinophils/HPF, in general, correlated with the overall number of eosinophils in a given case. Samples were classified as follows: $0=0$ eosinophils/HPF; $1=1$ to 25 eosinophils/HPF; $2=$ more than 25 eosinophils/HPF.

\section{Statistical Analysis}

Cases of NLPHL, reactive lymphoid hyperplasia, and the various subtypes of NHL were used as separate control groups and compared against cases of classical HD using the Fisher exact test (20). The Kruskal-Wallis test (21) was used to determine correlations between MDC mRNA and protein expression, MDC expression in whole and TMA sections, and MDC expression and tissue eosinophilia. 
All statistical calculations were performed using the SAS program.

\section{RESULTS}

\section{Expression in Hodgkin's Lymphoma}

To evaluate MDC protein expression and the microanatomical localization in Hodgkin's lymphoma tissues, we performed immunohistochemical analyses on formalin-fixed, paraffin embedded tissues. A total of $57 \mathrm{HD}$ cases (18 LP, 11 MC, 28 NS) were evaluated (Table 1). RS cells in classical HD consistently showed the highest level of MDC expression. Twenty-five of 28 NS (89\%) and 9 of $11 \mathrm{MC}$ cases $(82 \%)$ were immunoreactive for MDC (Fig. 1B). In most cases (21 of 28 NS and 6 of $11 \mathrm{MC}$ ), RS cells showed a moderate to high level of diffuse cytoplasmic staining (2+ to $3+$ ). A few cases (3 of 28 NS and 2 of $11 \mathrm{MC}$ ) showed no MDC staining in RS cells. Typically, staining of positive RS cells was uniformly strong, often with a Golgi-like subcellular enhancement, whereas only rare histiocytes, cells with the appearance of activated B cells or immunoblasts, and endothelial cells showed weak, cytoplasmic staining. Surrounding plasma cells, lymphocytes, and eosinophils in HD tissues were uniformly nonreactive. As opposed to the consistent staining pattern of CHD, L\&H cells in LP HD cases were negative for MDC (15 of 18) or showed focal weak staining $(1+$ in 3 of 18) in rare scattered histiocytes. In hyperplastic lymph nodes (7 cases), only rare histiocytes were weakly positive. On the basis of the intensity of MDC staining alone, we were able to distinguish CHD (NS and MC as a group) from LPHD $(P<.001)$ and reactive lymphoid hyperplasia as controls. The pattern of MDC staining of RS cells in CHD was readily distinguishable from the weak staining of occasional histiocytes in CHD, LPHD, or RLH. An HD tissue microarray was stained for a panel of relevant markers (CD3, CD20, CD30, LeuM1) including MDC. RS $\left(\mathrm{CD} 30^{+}\right)$or $\mathrm{L} \& \mathrm{H}\left(\mathrm{CD} 20^{+}\right)$cells were readily visualized in TMA cores (Fig. 1A) and showed a similar pattern of MDC staining as compared with whole sections (Fig. 1B). Overall, there was a high degree of concordance $(P<.001)$ between MDC staining of whole sections and TMA cores.

We have previously shown that MDC mRNA expression detected by semiquantitative RT-PCR was highest in the NS subtype of HD (MDC was also detected in some MC cases; 4), however, because of limitations of the technique, we were unable to localize expression to RS cells. The 16 HD cases previously analyzed for MDC mRNA expression (5 LP, 4 MC, 7 NS, from the NCI) comprise a subset of
TABLE 1. Clinical Characteristics: MDC Expression and Eosinophilia

\begin{tabular}{|c|c|c|c|c|c|}
\hline Patient & Site & $\begin{array}{l}\text { Age } \\
\text { (y) }\end{array}$ & Gender & $\begin{array}{c}\mathrm{IHC} \\
\mathrm{MDC}^{\mathrm{V}}\end{array}$ & $\begin{array}{c}\text { Extent of } \\
\text { Eosinophilia* }\end{array}$ \\
\hline \multicolumn{6}{|l|}{ LP } \\
\hline 1 & LN, R axilla & 21 & M & 0 & 0 \\
\hline 2 & LN, R axilla & 21 & $\mathrm{~F}$ & 0 & 0 \\
\hline 3 & ST submental & 40 & M & 0 & 0 \\
\hline 4 & LN, R axilla, Med & 40 & M & 0 & 0 \\
\hline 5 & Parotid & 19 & M & 1 & 0 \\
\hline 6 & LN, L cervical & 29 & M & 0 & 0 \\
\hline 7 & LN, R scalene & 34 & $\mathrm{~F}$ & 0 & 0 \\
\hline 8 & LN, L jugular & 15 & $\mathrm{~F}$ & 0 & 0 \\
\hline 9 & LN, $\mathrm{R}$ axilla & 36 & M & 0 & 0 \\
\hline 10 & LN, L inguinal & 39 & M & 0 & 0 \\
\hline 11 & LN, R groin & 34 & M & 0 & 0 \\
\hline 12 & LN, R axilla & 29 & M & 1 & 0 \\
\hline 13 & LN, celiac & 24 & M & 1 & 0 \\
\hline 14 & LN, L inguinal & 23 & M & 0 & 0 \\
\hline 15 & L Neck mass & 9 & M & 0 & 0 \\
\hline 16 & LN, L neck & 57 & M & 0 & 0 \\
\hline 17 & LN, L neck & 42 & $\mathrm{~F}$ & 0 & 0 \\
\hline 18 & LN, R inguinal & 49 & $\mathrm{~F}$ & 0 & 0 \\
\hline \multicolumn{6}{|l|}{ MC } \\
\hline 1 & Med & 19 & $\mathrm{~F}$ & 3 & 2 \\
\hline 2 & LN, L scalene & 37 & M & 3 & 2 \\
\hline 3 & R scapula & 14 & M & 1 & 0 \\
\hline 4 & Med & 35 & $\mathrm{~F}$ & 1 & 1 \\
\hline 5 & LN, R axilla & 51 & $\mathrm{~F}$ & 3 & 1 \\
\hline 6 & LN, R pelvis & 32 & M & 2 & 1 \\
\hline 7 & LN, L axilla & 49 & $\mathrm{~F}$ & 3 & 0 \\
\hline 8 & LN & 69 & $\mathrm{~F}$ & 1 & 1 \\
\hline 9 & Mediastinum & 46 & M & 0 & 0 \\
\hline 10 & LN, R scalene & 45 & M & 2 & 1 \\
\hline 11 & LN, cervical & 84 & $\mathrm{~F}$ & 0 & 0 \\
\hline \multicolumn{6}{|l|}{ NS } \\
\hline 1 & L neck mass & 43 & $\mathrm{~F}$ & 2 & 2 \\
\hline 2 & LN, R axilla & 61 & $\mathrm{~F}$ & 0 & 0 \\
\hline 3 & Pleura & 69 & $\mathrm{~F}$ & 0 & 1 \\
\hline 4 & LN, R groin & 40 & M & 3 & 1 \\
\hline 5 & Med, pericardium & 29 & M & 3 & 1 \\
\hline 6 & LN, R supraclavicular & 25 & M & 2 & 1 \\
\hline 7 & LN, L cervical & 38 & $\mathrm{~F}$ & 3 & 1 \\
\hline 8 & LN, R neck & 39 & M & 1 & 0 \\
\hline 9 & LN, R cervical & 15 & $\mathrm{~F}$ & 2 & 1 \\
\hline 10 & LN, R supraclavicular & 36 & $\mathrm{~F}$ & 3 & 1 \\
\hline 11 & LN, L neck & 37 & M & 3 & 1 \\
\hline 12 & LN, R neck & 27 & $\mathrm{~F}$ & 3 & 1 \\
\hline 13 & LN Med & 51 & M & 3 & 1 \\
\hline 14 & Lung & 21 & $\mathrm{~F}$ & 3 & 1 \\
\hline 15 & Lung & 50 & $\mathrm{~F}$ & 3 & 1 \\
\hline 16 & LN, R supraclavicular & 27 & $\mathrm{~F}$ & 1 & 1 \\
\hline 17 & LN, L ext iliac & 33 & M & 1 & 1 \\
\hline 18 & Chest wall, pleura & 16 & $\mathrm{~F}$ & 2 & 1 \\
\hline 19 & LN, R cervical & 27 & M & 3 & 0 \\
\hline 20 & LN, portal & 27 & $\mathrm{~F}$ & 3 & 1 \\
\hline 21 & Med & 69 & M & 3 & 1 \\
\hline 22 & $\mathrm{R}$ neck & 45 & $\mathrm{~F}$ & 2 & 1 \\
\hline 23 & Pelvic mass & 78 & M & 3 & 2 \\
\hline 24 & LN, R cervical & 36 & $\mathrm{~F}$ & 3 & 1 \\
\hline 25 & LN R, inguinal & 54 & $\mathrm{~F}$ & 0 & 0 \\
\hline 26 & Med & 38 & M & 3 & 2 \\
\hline 27 & LN, L cervical & 27 & $\mathrm{~F}$ & 1 & 1 \\
\hline 28 & Pericardium & 45 & M & 3 & 1 \\
\hline
\end{tabular}

$\mathrm{LN}=$ lymph node, $\mathrm{R}=$ right, $\mathrm{L}=\mathrm{Left}, \mathrm{Med}=$ mediastinum, $\mathrm{ST}=$ soft tissue.

* Grade of tissue eosinophilia was determined: $0=$ no eosinophils high power field; $1=1-25$ eosinophils/high power field; $2=>25$ eosinophils/high power field.

${ }^{\mathrm{V}}$ IHC MDC score: $0=$ no staining in RS cells; $1+=$ faint staining in $<10 \%$ of RS cells; $2+=$ moderate staining in $10-50 \%$ of RS cells; $3+=$ homogeneously intense staining in $>50 \%$ of RS cells.

the total of 57 HD cases stained for MDC expression. Using a four-grade scale to score MDC immunohistochemical staining ( 0 to $3+$ ), there was a 
significant correlation $(P=.0071)$ between levels of MDC mRNA expression and MDC protein detected by immunohistochemistry (Fig. 2) in these $16 \mathrm{HD}$ cases, supporting the RS cells as the primary origin of MDC production.

\section{Expression in Non-Hodgkin's Lymphoma} and Normal Hematolymphoid Tissues

To rapidly survey the specificity of MDC expression in neoplastic and normal lymphoid tissues, we prepared a tissue microarray representing 87 cases of several common NHL subtypes including CLL/ SLL $(n=13)$, FL $(n=36)$, DLBL $(n=26)$, ALCL $(n$ $=2)$, MCL $(n=5)$, and MZL $(n=5)$. This panel of cases has been characterized for expression of CD3, CD5, CD10, CD20, CD23, CD43, BCL-2, BCL-6, Cyclin D1, P53, and MIB-1 (CVH, JT-F, unpublished results). Focal, weak MDC immunoreactivity was observed in tumor cells in 5 of 26 DLBL, 1 of 2 ALCL, 1 of 13 CLL, and 2 of 36 FL. Most cases were either entirely negative for MDC; or in 1 of 13 CLL, 1 of 5 MZL, and 6 of 36 FL, there was weak staining of occasional histiocytes and immunoblasts. In a separate analysis using whole sections, seven cases of TCRBCL and 8 additional cases of ALCL were stained for MDC. Neoplastic cells were nonreactive for MDC in all cases of TCRBCL and ALCL, and only very weak staining of rare, scattered histiocytes was observed.

Several normal hematolymphoid tissues were also represented on the array, including lymph node $(n=6)$, spleen $(n=6)$, thymus $(n=2)$, and tonsil $(n=1)$. In lymph nodes, there was weak MDC staining of rare histiocytes. Lymphocytes in

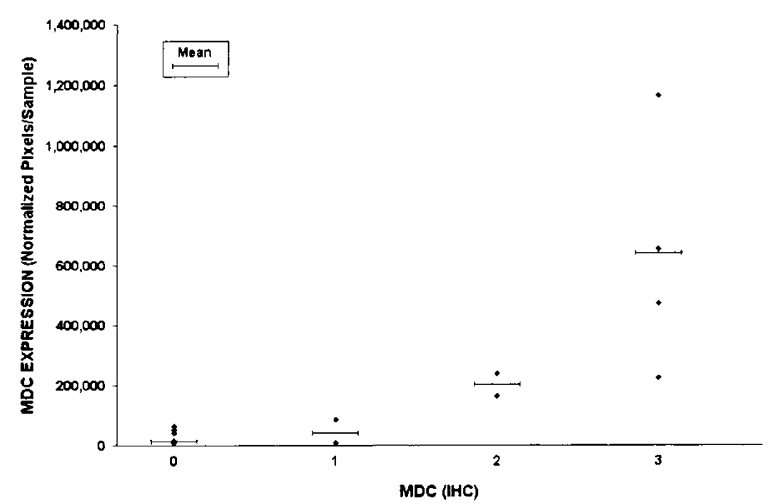

FIGURE 2. Correlation of MDC immunoreactivity and MDC mRNA expression in Hodgkin's lymphoma. Total cellular RNA, extracted from paraffin-embedded HD tissues and lymphoid hyperplasia, was subjected to semiquantitative RT-PCR. After normalization to a standard RNA preparation and to G3PDH, the results of PhosphorImager analysis are shown as normalized arbitrary units (pixels)/sample. The arithmetic mean is indicated for each group (mean bar). Immunohistochemical analysis for MDC was scored as follows: 0 $=$ negative in RS cells; $1+=$ faint staining in less than $10 \%$ of RS cells; $2+=$ moderate staining in $10-50 \%$ of RS cells; $3+=$ homogeneously intense staining in more than $50 \%$ of RS cells. lymph node, spleen, and tonsil were uniformly nonreactive. In the thymus, there was rare, weak MDC staining of occasional histiocytes, both in array cores and in two additional whole sections examined. Both thymic lymphocytes and epithelial cells were negative for MDC. In the spleen and tonsil, there was no MDC immunoreactivity.

\section{Expression and Tissue Eosinophilia}

Because MDC has been shown to act as a chemoattractant for eosinophils in vitro (10), we determined whether there was a correlation between the extent of tissue eosinophilia and the immunohistochemical expression of MDC. There was a significant direct correlation $(P<.001)$ between MDC protein expression and eosinophilia in HD tissues (Table 1). Not surprisingly, cases of classical HD had greater eosinophilia and higher MDC expression than did LPHD cases. A common feature of HD is the presence of a T-cell infiltrate, in which CD4+ cells predominate (22). Although it is reported that $\mathrm{MDC}$ is chemoattractant for $\mathrm{CD} 3+\mathrm{CD} 4+\mathrm{CD} 8^{\text {low }}$ thymocytes (22), as visualized by immunohistochemical stains for CD4 and CD8 performed on HD TMA sections (data not shown), there was no significant difference in the relative numbers and intensity of staining of $\mathrm{CD} 4+$ versus $\mathrm{CD} 8+\mathrm{T}$ cell infiltrates. In cases in which there was a significant $\mathrm{CD}^{+}{ }^{+} \mathrm{T}$ cell infiltrate, no MDC expression was observed in these cells.

\section{DISCUSSION}

The major goal of this study was to define the cellular origin of MDC protein expression in HD and to correlate its expression with HD subtype and tissue eosinophilia. Our results demonstrate high levels of MDC expression in RS cells of classical Hodgkin's lymphoma (both nodular sclerosis and mixed cellularity). MDC expression is specific for CHD because only focal weak staining of occasional L\&H cells and histiocytes was observed in a few cases of LP HD and in reactive lymphoid hyperplasia. Using tissue microarrays to survey MDC expression in NHL cases, only low levels were observed in a minority of cases. We also demonstrated that the TMA technique could be successfully applied to the study of HD.

In our previous study, only the NS subtype of HD has significantly higher MDC mRNA levels. Although some MC cases did have similarly high MDC levels, the difference was not substantial enough in the small number of cases examined to be able to establish a reliable correlation. In the present study, there was not a significant difference between NS and MC subtypes, which both showed 
similarly high MDC protein levels, but we were able to distinguish NS and MC as a group from LPHD.

Although we observed weak MDC staining of rare tumor cells in some cases of LPHD, ALCL, CLL, FL, and DLBL, the intensity was similar to that observed in histiocytes or immunoblasts in similar cases, and in normal tissues. MDC expression was not detected in surrounding infiltrating cells such as lymphocytes, plasma cells, or eosinophils except for low levels in occasional histiocytes. This pattern differs somewhat from what we have shown for eotaxin, which is expressed not only in RS cells of CHD but also by macrophages, lymphocytes, medial smooth-muscle cells of vessels, and fibroblasts (4). The specificity of expression of the closely related chemokine TARC that binds to the same CCR4 receptor is similar, with highest levels in RS cells in NS and MC HD, although 2 of 5 cases of TCRBCL were also TARC positive by in situ hybridization and immunohistochemistry (5). In our study, no MDC expression was observed in tumor cells in cases of TCRBCL or ALCL. Another study that supports our results examined the expression profile of purified RS cells and Hodgkin's cell lines and found high levels of MDC mRNA expression as compared with germinal center B cells (23). Others have reported MDC immunoreactivity in thymic medullary epithelial cells (24), which we did not observe in either whole or TMA sections. This may be because in the other study, paraformaldehyde-fixed cryostat sections were used instead of paraffin-embedded material. Nevertheless, on the basis of our previously published results on mRNA expression analysis of MDC in reactive lymph nodes and LPHD, we believe that the sensitivity of immunohistochemistry is sufficient to exclude expression in negative cases. There was a statistically significant correlation with mRNA and protein expression of MDC. In vitro studies have observed induction of MDC expression in activated B cells, which may represent some of the positive, apparently normal cells in HD and normal tissues.

Our results show that HD cases with high levels of MDC expression have a denser eosinophilic infiltrate than cases that have a low level or are negative for MDC. This finding is consistent with the eosinophil chemotactic property of MDC observed in vitro (10). Another chemokine expressed in HD tissues, eotaxin, is also chemotactic for eosinophils. The differential roles for these factors with overlapping functions are not currently understood. MDC is also chemotactic for dendritic cells, NK cells, the Th2 subset of peripheral blood $\mathrm{T}$ cells, and $\mathrm{CD}^{+}{ }^{+} \mathrm{CD} 4{ }^{+} \mathrm{CD} 8{ }^{\text {low }}$ thymocytes (24). CCR4 is expressed by $\mathrm{T}$ cells surrounding the RS cells, but not by eosinophils. Therefore, although it is possible that the correlation between MDC and tissue eosinophilia may be indirect, we cannot exclude the possibility that MDC may be functioning in conjunction with eotaxin, however, through different receptors and signaling mechanisms via CCR3, CCR4, or CCR5 (25). Another mechanism such as MDC acting via a different chemokine receptor that is present on eosinophils may also be involved in eosinophil recruitment.

Tissue microarrays proved to be a rapid highthroughput technique to study the expression of MDC in a variety of NHL subtypes. Once the cases are collected, the construction of the array is relatively straightforward. This technique is probably most appropriate for the initial screening with a new antibody or ISH probe to determine the range of expression and microanatomical localization. This report represents the first study of the application of this technique to HD. The ability to examine a large number of cases on a single slide should also allow for patient or clinical protocol studies if the antigen is uniformly expressed throughout the tissue sample.

Some cases in which MDC mRNA was detected showed no MDC immunoreactivity. In general, these were cases with a relatively low MDC mRNA level. Given that immunohistochemical detection methods are less sensitive than RT-PCR, this result is not unexpected. In general, cases with relatively high MDC mRNA levels were positive by IHC.

Unlike other chemokines, such as IP-10 and Mig, MDC is more specific to RS cells than surrounding reactive lymphocytes, eosinophils, and fibroblasts. This specific-expression pattern of RS cells makes MDC a candidate target for therapeutic intervention or as a diagnostic marker in difficult cases. These results suggest that MDC may play an important role in eosinophil recruitment in HD tissues.

Acknowledgments: We thank Marina Asherov and Irina Linkov in the Immunohistochemistry Core Laboratory, SKI, directed by Dr. Victor Reuter, and David Kuo for their helpful contribution to this work.

\section{REFERENCES}

1. Gruss HJ, Pinto A, Duyster J, Poppema S, Herrmann F. Hodgkin's disease: a tumor with disturbed immunological pathways. Immunol Today 1997;18:156-63.

2. Gorschluter M, Bohlen H, Hasenclever D, Diehl V, Tesch H. Serum cytokine levels correlate with clinical parameters in Hodgkin's disease. Ann Oncol 1995;6:477-82.

3. Foss HD, Herbst H, Gottstein S, Demel G, Araujo I, Stein H. Interleukin-8 in Hodgkin's disease. Preferential expression by reactive cells and association with neutrophil density. Am J Pathol 1996;148:1229-36.

4. Teruya-Feldstein J, Jaffe ES, Burd PR, Kingma DW, Setsuda JE, Tosato G. Differential chemokine expression in tissues involved by Hodgkin's disease: direct correlation of eotaxin expression and tissue eosinophilia. Blood 1999;93:2463-70. 
5. van den Berg A, Visser L, Poppema S. High expression of the CC chemokine TARC in Reed-Sternberg cells. A possible explanation for the characteristic T-cell infiltrate in Hodgkin's lymphoma. Am J Pathol 1999;154:1685-91.

6. Godiska R, Chantry D, Raport CJ, Sozzani S, Allavena P, Leviten D, Mantovani A, Gray PW. Human macrophagederived chemokine (MDC), a novel chemoattractant for monocytes, monocyte-derived dendritic cells, and natural killer cells. J Exp Med 1997;185:1595-604.

7. Ghia P, Schaniel C, Rolink AG, Nadler LM, Cardoso AA. Human macrophage-derived chemokine (MDC) is strongly expressed following activation of both normal and malignant precursor and mature B cells. Curr Top Microbiol Immunol 1999;246:103-10.

8. Galli G, Chantry D, Annunziato F, Romagnani P, Cosmi L, Lazzeri E, Manetti R, Maggi E, Gray PW, Romagnani S. Macrophage-derived chemokine production by activated human $\mathrm{T}$ cells in vitro and in vivo: preferential association with the production of type 2 cytokines. Eur J Immunol 2000;30:204-10.

9. Rodenburg RJ, Brinkhuis RF, Peek R, Westphal JR, Van Den Hoogen FH, van Venrooij WJ, van de Putte LB. Expression of macrophage-derived chemokine (MDC) mRNA in macrophages is enhanced by interleukin-1beta, tumor necrosis factor alpha, and lipopolysaccharide. J Leukoc Biol 1998;63:606-11.

10. Bochner BS, Bickel CA, Taylor ML, MacGlashan DW Jr, Gray PW, Raport CJ, Godiska R. Macrophage-derived chemokine induces human eosinophil chemotaxis in a CC chemokine receptor 3- and CC chemokine receptor 4-independent manner. J Allergy Clin Immunol 1999;103(3 Pt 1):527-32.

11. Staudt LM. The molecular and cellular origins of Hodgkin's disease. J Exp Med 2000;191:207-12.

12. Eghbali H, Soubeyran P, Tchen N, de Mascarel I, Soubeyran I, Richaud P. Current treatment of Hodgkin's disease. Crit Rev Oncol Hematol 2000;35:49-73.

13. Teruya-Feldstein J, Tosato G, Jaffe ES. The role of chemokines in Hodgkin's disease. Leuk Lymphoma 2000;38:363-71.

14. Kononen J, Bubendorf L, Kallioniemi A, Barlund M, Schraml P, Leighton S, Torhorst J, Mihatsch MJ, Sauter G, Kallioniemi OP. Tissue microarrays for high-throughput molecular profiling of tumor specimens Nat Med 1998;4:844-7.

15. Sallinen SL, Sallinen PK, Haapasalo HK, Helin HJ, Helen PT, Schraml P, Kallioniemi OP, Kononen J. Identification of differentially expressed genes in human gliomas by DNA microarray and tissue chip techniques. Cancer Res 2000;60: 6617-22.
16. Schraml P, Kononen J, Bubendorf L, Moch H, Bissig H, Nocito A, Mihatsch MJ, Kallioniemi OP, Sauter G. Tissue microarrays for gene amplification surveys in many different tumor types. Clin Cancer Res 1999;5:1966-75.

17. Richter J, Wagner U, Kononen J, Fijan A, Bruderer J, Schmid U, Ackermann D, Maurer R, Alund G, Knonagel H, Rist M, Wilber K, Anabitarte M, Hering F, Hardmeier T, Schonenberger A, Flury R, Jager P, Fehr JL, Schraml P, Moch H, Mihatsch MJ, Gasser T, Kallioniemi OP, Sauter G. Highthroughput tissue microarray analysis of cyclin E gene amplification and overexpression in urinary bladder cancer. Am J Pathol 2000;157:787-94.

18. Natkunam Y, Warnke RA, Montgomery K, Falini B, van De Rijn M. Analysis of mum1/irf4 protein expression using tissue microarrays and immunohistochemistry. Mod Pathol 2001;14:686-94.

19. Harris NL, Jaffe ES, Diebold J, Flandrin G, Muller-Hermelink HK, Vardiman J, Lister TA, Bloomfield CD. The World Health Organization classification of neoplastic diseases of the haematopoietic and lymphoid tissues: Report of the Clinical Advisory Committee Meeting, Airlie House, Virginia, November 1997. Histopathology 2000;36:69-86.

20. Rosner B. Hypothesis testing: categorical data. In: Fundamentals of biostatistics. Belmont, CA: Wadsworth; 1994. p. $187-220$.

21. Rosner B. Nonparametric methods. In. Fundamentals of biostatistics. Belmont, CA: Wadsworth; 1994. p. 551-84.

22. Pinkus GS, Barbuto D, Said JW, Churchill WH. Lymphocyte subpopulations of lymph nodes and spleens in Hodgkin's disease. Cancer 1978;42:1270-9.

23. Cossman J, Annunziata CM, Barash S, Staudt L, Dillon P, He WW, Ricciardi-Castagnoli P, Rosen CA, Carter KC. ReedSternberg cell genome expression supports a B-cell lineage. Blood 1999;94:411-6.

24. Chantry D, Romagnani P, Raport CJ, Wood CL, Epp A, Romagnani S, Gray PW. Macrophage-derived chemokine is localized to thymic medullary epithelial cells and is a chemoattractant for $\mathrm{CD} 3(+)$, CD4 $(+)$, CD8(low) thymocytes. Blood 1999;94:1890-8.

25. Buri C, Korner M, Scharli P, Cefai D, Uguccioni M, Mueller C, Laissue JA, Mazzucchelli L. CC chemokines and the receptors CCR3 and CCR5 are differentially expressed in the nonneoplastic leukocytic infiltrates of Hodgkin disease. Blood 2001;97:1543-8. 